\title{
COVID-19 Epidemic and Spirituality: A Review of the Benefits of Religion in Times of Crisis
}

\author{
Mohammad Ali Fardin (iD) 1, \\ ${ }^{1}$ Department Of Psychology, Zahedan Branch, Islamic Azad University, Zahedan, Iran \\ "Corresponding author: Department Of Psychology, Zahedan Branch, Islamic Azad University, Zahedan, Iran. Tel: +98-9155401527, Email: fardinmohamadali@yahoo.com
}

Received 2020 April 27; Revised 2020 May 16; Accepted 2020 May 17.

\begin{abstract}
Context: The current world crisis, COVID-19 disease, is different from any other world's previous crises since it has killed thousands of people all around the world and made the medical science desperate. During the COVID-19 outbreak, spirituality can be one of the proper methods to create mental relaxation.

Evidence Acquisition: The present study is a review of the literature from 1978 to 2019. The search was done in electronic databases and reputable websites including PubMed, Medline, Springer, Elsevier, Science Direct, Scopus, and SID for both English and nonEnglish language articles using the following keywords: "spirituality", "prayer", "and "some religious advice were assessed in times of crisis". A total of 11 articles were selected for review.

Results: The results indicated that spirituality could aid people to have mental relaxation in times of crisis and dangerous diseases. Some of the religious solutions proposed against the COVID-19 prevalence could be helpful.

Conclusions: Since a long time ago, religions have attempted to provide behavioral pieces of advice in times of crisis to help humankind spiritually. In the present study, some of these pieces of advice are mentioned. It has been suggested that medical staff in hospitals pay more attention to the spiritual and religious beliefs of COVID-19-infected patients to improve their calmness and well-being.
\end{abstract}

Keywords: COVID-19, Epidemic, Spirituality, Religion, Crisis

\section{Context}

The Coronavirus Disease 2019 (COVID-19) epidemic is known as a global health crisis that has caused huge mental and health challenges in the world (1). Initially, COVID19 was reported in China in late 2019 and then spread to 13 countries by January 24, 2020 (2). This disease that occurred first in Wuhan is an emerging infectious disease (3). In Iran, there was a growing trend of the disease showing that until March 1, 2020, there were 987 infected people and 54 deaths (4). By mid-May, the prevalence rate raised to 112,725 infected cases and 6,783 deaths. Turkey is another Islamic country with the highest rate of COVID-19-infected cases, reporting 143,114 infected people, and 3,925 deaths (5) In addition to endangering human health, COVID-19 imposes irreversible psychological impacts on human societies. Among these influences, we can mention the effects of quarantine and lockdown, the fear of infection, the anxiety of losing loved ones, and depression arising after losing friends and family members (6).

In the current global situation that the number of COVID-19 deaths is updated and published daily, spiritual- ity can be a good sedative in societies facing the outbreak (7). Several religions, despite all their limitations, create positive emotions in people. Spirituality and religion can help humans in bereavement and times of crisis (8). Although, for a long time, epidemiologists have been trying to answer this question that whether spirituality and religion are associated with mortality and health (9), the majority of the internal medicine specialists have positive attitudes towards spirituality (10). The study of dialogues between religion and psychology is difficult because experts in psychology often lack a strong understanding of religious traditions, and it requires to understand basic problems and materials to connect religion with psychology (11). Various longitudinal and cross-sectional studies carried out around the world support the theory of the correlation between spirituality and better physical and mental health (12-14). Religions have positive impacts on human mental health through conducting health measures, providing social support, and enhancing self-efficacy and cohesion (15). As an instance, "If you hear that plague or any other dangerous infectious disease has broken out in a 
land, do not go to it; but if it breaks out in a land where you are living, stay at home in your city", said the Prophet of Islam nearly 1,400 years ago (16). "Cleanliness is half of the faith and faith leads a man to heaven", said the Prophet of Islam in another part (17). Furthermore, ablution (wudhu') is one of the Islamic washing rituals performed before each prayer, five times a day, by doing which a person washes his hands, forearms, mouth, nose, ears, face, hair, ankles, and feet, three times each (17). Thus, it includes all of the most effective ways of dealing with COVID-19. Islam is the main religion in Iran (18) that allowed Iranian families to pray together and spend more time to read the Holy Quran during the COVID pandemic. Research has shown that religious practices are associated with many health consequences $(19,20)$. Spirituality and religion can be useful sedatives for humankind in the current status quo. Accordingly, the present study was conducted to review the benefits of religion and spirituality in times of crisis.

\section{Evidence Acquisition}

The present study is a review of the literature published from 1978 to 2019. The search was done in electronic databases and reputable websites including PubMed, Medline, Springer, Elsevier, Science Direct, Scopus, and SID for both English and non-English language articles using the following keywords: "spirituality", "prayer", "and "some religious advice were assessed in times of crisis".

\section{Results}

A total of 11 articles were selected for review (Table 1).

\section{Conclusions}

When most people were worried about environmental disasters leading to an unknown future, the outbreak of COVID-19 shocked them by killing thousands of people. The depth of this tragedy has been such that people have to stay at home in quarantine, constantly listening to the news of the death toll. Whereas most professionals around the world are trying to prevent further spread of COVID19, spirituality, and prayer, which have received little attention, can calm people down. One of the most important sources of human character and identity is religion, which has not been considered deeply in clinics (29). It is believed that religions caused some problems during the COVID-19 pandemic (30), but Muslims have done valuable protective activities to combat the spread of this disease, such as canceling the Friday prayer and congregational prayer (31). When the Ebola disease broke out in

\begin{tabular}{|c|c|c|c|}
\hline $\begin{array}{l}\text { Author } \\
\text { (Refer- } \\
\text { ence) }\end{array}$ & Year & $\begin{array}{l}\text { Study } \\
\text { Design }\end{array}$ & Outcomes \\
\hline $\begin{array}{l}\text { Bonelli } \\
(21)\end{array}$ & 1978 & $\begin{array}{l}\text { Systematic } \\
\text { review }\end{array}$ & $\begin{array}{l}\text { In more than } 70 \% \text { of the studies, there } \\
\text { was a strong relationship between } \\
\text { religious involvement and better } \\
\text { mental health }\end{array}$ \\
\hline $\begin{array}{l}\text { Pattison } \\
(22)\end{array}$ & 2013 & Perspective & $\begin{array}{l}\text { Religion was an essential requirement } \\
\text { for health care institutions }\end{array}$ \\
\hline $\begin{array}{l}\text { Vaillant } \\
\text { (7) }\end{array}$ & 2013 & $\begin{array}{l}\text { Cross- } \\
\text { sectional }\end{array}$ & $\begin{array}{l}\text { Spirituality, including emotions and } \\
\text { social interactions, depended on the } \\
\text { limbic system }\end{array}$ \\
\hline $\begin{array}{l}\text { Chaves et } \\
\text { al. (23) }\end{array}$ & 2015 & $\begin{array}{l}\text { Cross- } \\
\text { sectional }\end{array}$ & $\begin{array}{l}\text { The strategy of spirituality was a } \\
\text { practical and appropriate solution to } \\
\text { resolve university students' anxiety }\end{array}$ \\
\hline $\begin{array}{l}\text { Ahmadi } \\
\text { et al. }(24)\end{array}$ & 2015 & Review & $\begin{array}{l}\text { Spirituality and religion are useful in } \\
\text { the palliative treatment of patients } \\
\text { with cancer. }\end{array}$ \\
\hline $\begin{array}{l}\text { Jakovljevic } \\
(19)\end{array}$ & 2017 & Perspective & $\begin{array}{l}\text { Psychiatry and religion could } \\
\text { creatively help improve the world in } \\
\text { the current global crisis }\end{array}$ \\
\hline $\begin{array}{l}\text { Chen and } \\
\text { Vander- } \\
\text { Weele } \\
\text { (13) }\end{array}$ & 2018 & Longitudinal & $\begin{array}{l}\text { In a large-scale longitudinal study } \\
\text { that examined the impact of religious } \\
\text { training on psychological health, } \\
\text { health behaviors, and physical health } \\
\text { of a group of adolescents for } 14 \text { years } \\
\text { until the subjects' adulthood, the } \\
\text { authors figured out that young adults } \\
\text { who attended religious ceremonies } \\
\text { had higher levels of life satisfaction } \\
\text { and were less likely to drink alcohol } \\
\text { and have out-of-marriage } \\
\text { relationships compared to their } \\
\text { counterparts }\end{array}$ \\
\hline $\begin{array}{l}\text { Renz et al. } \\
(25)\end{array}$ & 2018 & $\begin{array}{l}\text { Cross- } \\
\text { sectional }\end{array}$ & $\begin{array}{l}\text { Spirituality could facilitate the } \\
\text { process of death }\end{array}$ \\
\hline $\begin{array}{l}\text { Cramer et } \\
\text { al. (26) }\end{array}$ & 2018 & $\begin{array}{l}\text { Cross- } \\
\text { sectional }\end{array}$ & $\begin{array}{l}\text { Yoga was an effective intervention for } \\
\text { people suffering from high levels of } \\
\text { anxiety }\end{array}$ \\
\hline $\begin{array}{l}\text { Fidianingsil } \\
\text { et al. (27) }\end{array}$ & 2018 & $\begin{array}{l}\text { Cross- } \\
\text { sectional }\end{array}$ & $\begin{array}{l}\text { In a study investigating the effect of } \\
\text { fasting, one of the obligatory } \\
\text { practices of Islam, fasting showed to } \\
\text { reduce anxiety in the elderly }\end{array}$ \\
\hline $\begin{array}{l}\text { Sharma } \\
\text { and } \\
\text { Singh (28) }\end{array}$ & 2019 & $\begin{array}{l}\text { Cross- } \\
\text { sectional }\end{array}$ & $\begin{array}{l}\text { There were significant relationships } \\
\text { between gratitude, spirituality, } \\
\text { forgiveness, altruism, and well-being. }\end{array}$ \\
\hline
\end{tabular}

Nigeria, the federal government advised taking the counsel of Prophet Mohammad, who urged Muslims to cleanliness and wash their hands frequently (17). Cultural and religious faiths mainly influence patients' lives (32). Moreover, religiosity increases longevity (15). In the last century, views of religious experts and psychologists about the question of life meaning have changed (11). Religions can play roles as facilitators, friends, and even critics for special healthcare (22). The fact that religions are among social factors determining health is a general compromise among experts (20). Countless religions in the world can be learned like languages and create positive emotions in humans, and these positive states help us to survive in the unknown future (7). In the current global situation that 
humans live in anxiety and stress, and numerous studies have supported the positive effects of spirituality on people's mental health, especially in times of crisis and acute diseases, virtual worships and spiritual podcasts can be the perfect solutions to create mental relaxation and spirituality in people. It has been suggested that medical staff in hospitals pay more attention to the spiritual and religious beliefs of COVID-19-infected patients to improve their calmness and well-being. More importantly, various Islamic advice such as cleanliness and forbidding eating wild birds (Haram) like bats, known as the main reason for the transition of COVID-19, can protect humans against infectious disease pandemics.

\section{Footnotes}

Authors' Contribution: Mohammad Ali Fardin: Study concept, search for previous related articles, preparation of the paper, editing of the paper, and references.

Conflict of Interests: The authors report no conflicts of interest in this work.

Funding/Support: Present research has not been supported

\section{References}

1. Wang C, Pan R, Wan X, Tan Y, Xu L, Ho CS, et al. Immediate Psychological Responses and Associated Factors during the Initial Stage of the 2019 Coronavirus Disease (COVID-19) Epidemic among the General Population in China. Int J Environ Res Public Health. 2020;17(5). doi: 10.3390/ijerph17051729. [PubMed: 32155789].

2. Nishiura H, Jung SM, Linton NM, Kinoshita R, Yang Y, Hayashi K, et al. The Extent of Transmission of Novel Coronavirus in Wuhan, China, 2020.JClin Med.2020;9(2). doi: 10.3390/jcm9020330. [PubMed: 31991628]

3. Yang HY, Duan GC. [Analysis on the epidemic factors for the Corona Virus Disease]. Zhonghua Yu Fang Yi Xue Za Zhi. 2020;54(0). Chinese. E021. doi: 10.3760/cma.j.cn112150-20200227-00196. [PubMed: 32125129].

4. Zhuang Z, Zhao S, Lin Q, Cao P, Lou Y, Yang L, et al. Preliminary estimation of the novel coronavirus disease (COVID-19) cases in Iran: A modelling analysis based on overseas cases and air travel data. Int J Infect Dis. 2020. doi: 10.1016/j.ijid.2020.03.019. [PubMed: 32171951].

5. Worldometers. COVID-19 coronavirus pandemic. 2020, [cited 2020 March 29]. Available from: www.worldometers.info/coronavirus/.

6. Fardin M. COVID-19 and Anxiety: A Review of Psychological Impacts of Infectious Disease Outbreaks. Arch Clin Infect Dis. 2020;In Press(In Press). e102779. doi: 10.5812/archcid.102779.

7. Vaillant GE. Psychiatry, religion, positive emotions and spirituality. Asian J Psychiatr. 2013;6(6):590-4. doi: 10.1016/j.ajp.2013.08.073. [PubMed: 24309879].

8. Krysinska K, Andriessen K, Corveleyn J. Religion and spirituality in online suicide bereavement: an analysis of online memorials. Crisis. 2014;35(5):349-56. doi: 10.1027/0227-5910/a000270. [PubMed: 25189112].

9. Ransome Y. Religion Spirituality and Health: New Considerations for Epidemiology. Am J Epidemiol. 2020. doi: 10.1093/aje/kwaa022. [PubMed: 32128570].
10. Piscitello GM, Martin S. Spirituality, Religion, and Medicine Education for Internal Medicine Residents. Am J Hosp Palliat Care. 2020;37(4):2727. doi: 10.1177/1049909119872752. [PubMed: 31462061].

11. Nelson JM. Psychology, Religion, and Spirituality. USA: Springer, New York, NY; 2009.

12. VanderWeele TJ, Yu J, Cozier YC, Wise L, Argentieri MA, Rosenberg L, et al. Attendance at Religious Services, Prayer, Religious Coping, and Religious/Spiritual Identity as Predictors of All-Cause Mortality in the Black Women's Health Study. Am J Epidemiol. 2017;185(7):51522. doi: 10.1093/aje/kww179. [PubMed: 28338863]. [PubMed Central: PMC6354668].

13. Chen Y, VanderWeele TJ. Associations of Religious Upbringing With Subsequent Health and Well-Being From Adolescence to Young Adulthood: An Outcome-Wide Analysis. Am J Epidemiol. 2018;187(11):235564. doi: 10.1093/aje/kwy142. [PubMed: 30215663]. [PubMed Central: PMC6211237].

14. VanderWeele TJ. Spirituality and Religion within the Culture of Medicine: From Evidence to Practice. New York: Oxford University Press; 2017.

15. George LK, Ellison CG, Larson DB. Explaining the relationships between religious involvement and health. Psychol Inq. 2002;13(3):190-200.

16. Ghareeb BAA. Genetics of Diseases, Ethics and Beauty in Selection of Mates (An Islamic Perspective). Med J Islamic World Acad Sci. 2010;18(4):155-64.

17. Maigari YT. The relevance of the islamic principles on cleanliness to contemporary times: Focus on hand washing. Ilorin Journal of Religious Studies. 2016;6(2):91-104.

18. Weber SR, Pargament KI. The role of religion and spirituality in mental health. Curr Opin Psychiatry. 2014;27(5):358-63. doi: 10.1097/yco.0000000000000080. [PubMed: 25046080].

19. Jakovljevic M. Psychiatry and Religion: Opponents or Collaborators? The Power of Spirituality in Contemporary Psychiatry. Psychiatr Danub. 2017;29(Suppl 1):82-8. [PubMed: 28468026].

20. Kawachi I. Religion as a Social Determinant of Health. American Journal of Epidemiology. 2019. doi: 10.1093/aje/kwz204.

21. Bonelli RM. [Religiosity and Mental Health]. Dtsch Med Wochenschr. 2016;141(25):1863-7. German. doi: 10.1055/s-0042-109665. [PubMed: 27975362].

22. Pattison S. Religion, spirituality and health care: confusions, tensions, opportunities. Health Care Anal. 2013;21(3):193-207. doi: 10.1007/s10728-013-0245-4. [PubMed: 23568086].

23. Chaves Ede C, Iunes DH, Moura Cde C, Carvalho LC, Silva AM, de Carvalho EC. Anxiety and spirituality in university students: a cross-sectional study. Rev Bras Enferm. 2015;68(3):444-9. 504-9. doi: 10.1590/0034-7167.2015680318i. [PubMed: 26312523].

24. Ahmadi Z, Darabzadeh F, Nasiri M, Askari M. The Effects of Spirituality and Religiosity on Well-Being of People With Cancer: A Literature Review on Current Evidences. JundishapurJ Chronic Dis Care. 2015;4(2). e28386. doi: $10.5812 / j$ jicdc.28386.

25. Renz M, Reichmuth O, Bueche D, Traichel B, Mao MS, Cerny T, et al. Fear, Pain, Denial, and Spiritual Experiences in Dying Processes. Am J Hosp Palliat Care. 2018;35(3):478-91. doi: 10.1177/1049909117725271. [PubMed: 28823175]. [PubMed Central: PMC5794111].

26. Cramer H, Lauche R, Anheyer D, Pilkington K, de Manincor M, Dobos $\mathrm{G}$, et al. Yoga for anxiety: A systematic review and meta-analysis of randomized controlled trials. Depress Anxiety. 2018;35(9):830-43. doi: 10.1002/da.22762. [PubMed: 29697885].

27. Fidianingsih I, Jamil NA, Andriani RN, Rindra WM. Decreased anxiety after Dawood fasting in the pre-elderly and elderly. J Complement Integr Med. 2018;16(1). doi: 10.1515/jcim-2017-0172. [PubMed:30312161].

28. Sharma S, Singh K. Religion and Well-Being: The Mediating Role of Positive Virtues. J Relig Health. 2019;58(1):119-31. doi: 10.1007/s10943018-0559-5. [PubMed: 29353383]. 
29. Fischer J, Stope MB, Gumbel D, Hakenberg O, Burchardt M, Drager DL. [Influence of culture and religion on the treatment of cancer patients]. Urologe A. 2019;58(10):1179-84. German. doi: 10.1007/s00120019-1003-5. [PubMed: 31338523].

30. Wildman WJ, Bulbulia J, Sosis R, Schjoedt U. Religion and the COVID-19 pandemic. Religion, Brain \& Behavior. 2020;10(2):115-7.

31. Abdi M. Coronavirus disease 2019 (COVID-19) outbreak in Iran; ac- tions and problems. Infect Control Hosp Epidemiol. 2020:1-5. doi: 10.1017/ice.2020.86. [PubMed: 32192541].

32. Leong $\mathrm{M}$, Olnick S, Akmal T, Copenhaver A, Razzak R. How Islam Influences End-of-Life Care: Education for Palliative Care Clinicians. J Pain Symptom Manage. 2016;52(6):771-774 e3. doi: 10.1016/j.jpainsymman.2016.05.034. [PubMed: 27810572]. 